\title{
Effects of a low-voltage electric pulse charged to culture soil on plant growth and variations of the bacterial community
}

\author{
Jun Yeong $\mathrm{Yi}^{1}$, Ji Won $\mathrm{Choi}^{1}$, Bo Young Jeon ${ }^{1}$, II Lae Jung ${ }^{2}$, Doo Hyun Park ${ }^{1^{\star}}$ \\ ${ }^{1}$ Department of Biological Engineering, Seokyeong University, Seoul, Korea; \\ *Corresponding Author: baakdoo@skuniv.ac.kr \\ ${ }^{2}$ Department of Radiation Biology, Environmental Radiation Research Group, Korea Atomic Energy Research Institute, Daejeon, \\ Korea
}

Received 16 January 2012; revised 19 February 2012; accepted 20 March 2012

\begin{abstract}
This study was conducted to verify the effect of an electric pulse on growth of crops (lettuce and hot pepper) that were cultivated in lab-scale soil. The electric pulse generated from direct-circuited $2,4,6,8$, and $10 \mathrm{~V}$ of electricity by periodic exchange of the anode and cathode was charged to a culture soil that is an electrically pulsed culture soil (EPCS) but not charged to a conventional culture soil (CCS). Growth of lettuce increased and growth duration of hot pepper plants was more prolonged at $4,6,8$, and 10 $V$ of EPCS than at $2 \mathrm{~V}$ of EPCS and CCS. The fruiting duration and yield of hot pepper fruits were proportional to the growth duration of the hot pepper plants. Temperature gradient gel electrophoresis (TGGE) patterns of 16S-rDNA obtained from the bacterial community inhabiting the CCS and EPCS were identical at the initial time and did not change significantly at days 28 and 56 of cultivation. The bacterial communities inhabiting the surface of lettuce roots were not influenced by the electric pulse but were significantly different from those inhabiting the culture soil based on the TGGE patterns. Growth of lettuce and hot pepper plants that were cultivated in 4 - $10 \mathrm{~V}$ of EPCS may increase; however, the bacterial community inhabiting the soil and the surface of plant roots may not be influenced by an electric pulse.
\end{abstract}

Keywords: Electrically Pulsed Soil; TGGE; Lettuce; Hot Pepper Plant; Bacterial Community

\section{INTRODUCTION}

An electric pulse can be generated through soil located between an anode and cathode by periodic exchange of DC electrode poles. The electric charges generated by an electric pulse in water or watered soil may influence the physiology of microorganisms, the behavior of ionic compounds, and the oxidation-reduction potential [1,2]. High-intensity electric field pulses have been applied for food protection and microbial control for $>30$ years $[3,4]$. A very high electric pulse intensity $(2.0-5.0 \mathrm{~V} / \mu \mathrm{m}$ or $16.7 \mathrm{kV} / \mathrm{cm}$ ) completely inactivates Gram-positive, Gramnegative, and eukaryotic microorganisms under low temperature $\left(40^{\circ} \mathrm{C}\right)$ conditions [5] or under a low antibiotic concentration condition [6]. A low intensity electric pulse $\left(7 \mathrm{~mA} / \mathrm{cm}^{2}\right.$ or $\left.40 \mathrm{mV} / \mathrm{cm}\right)$ inhibits development of the biofilm growing on a carbon electrode, slightly inactivates bacterial growth, but activates yeast metabolism for ethanol production $[7,8]$. Seo et al. [9] applied a low intensity electric pulse $(0.28-0.3 \mathrm{~V} / \mathrm{cm})$ to farm field soil, and viable cell numbers of the soil bacterial community decreased significantly but bacterial diversity was not influenced. The influences of electric charge, electrically pulsed charges, or electrochemical redox reactions on growth or physiological variation of plants have not been investigated. However, the electrochemical redox reaction has been applied to measure the biological signal generated from plants as well as redox reactions in plant cell culture. Volkov [10] reported that bioelectrochemical signals generated between plant tissues and organs were influenced by soil environmental variations, while Chalmers et al. [11] observed ferricyanide-ferrocyanide redox reactions generated with proton extrusion in a carrot cell suspension culture. The membrane potential variation of plant cells and tissues leads to turgor-mediated motion and is associated with intracellular movements of plant cells, whereas electrical impulses comparable to those in higher plants regulate cilia and flagella activity in the motile gametes and spores of lower plants $[12,13]$. Many carnivorous plants use rapid 
trap movements to capture their animal prey, and the movements are mediated by electrical activity in some species [14]. Racusen and Etherton (1975) reported that adhesion of root tips is associated with a sudden change in surface charge of the root cap epidermal cells [15]. These previous studies showed that the electric or electrochemical potential variation may be related with plant biochemical reactions.

In this study, a low intensity electric pulse was charged into lab-scale culture soil, in which lettuce and hot pepper plants were cultivated. Roots of the plants grown in the electrically pulsed culture soil may respond to the unfamiliar signal generated by the electric pulse by morphologically measured parameters rather than biochemically measured parameters. Differences in size, growth duration, fruit yield, and soil bacterial community were observed and analyzed. This study was designed to estimate the influence of an electric pulse on the soil bacterial community, plant growth, crop yield, growth duration time, and fruit yield using lettuce and hot pepper plants.

\section{MATERIALS AND METHODS}

\subsection{Preparation of Lab-Scale Farm Field}

A six-compartmented lab-scale farm field was designed to effectively equip electrodes in culture soil for plant growth. Width, length, and depth of each compartment were adjusted to $120 \mathrm{~mm}, 1000 \mathrm{~mm}$, and $200 \mathrm{~mm}$, respectively. The commercially available compost soil that was used as culture soil was composed of cocopeat $(65 \%-70 \%)$, peat moss $(8 \%-12 \%)$, vermiculite $(10 \%$ $14 \%)$, zeolite $(3 \%-5 \%)$, and perlite $(5 \%-8 \%)$ according to the product information provided on the label (Baroker, Seoulbio, Chungcheongbuk-do, Korea).

\subsection{Electrode Placement}

Titanium plates (length, $1000 \mathrm{~mm}$; height, $200 \mathrm{~mm}$; thickness. $1 \mathrm{~mm}$ ) were placed on each side of the compartments of the lab-scale farm field, and the distance between electrodes was adjusted to $120 \mathrm{~mm}$ (Figure 1). Two, 4, 6, 8, or $10 \mathrm{~V}$ of direct current electric pulse was charged into the titanium to induce electrochemical variations in the soil environment around roots but the electric pulse was not charged for the CCS. The electrodes poles were periodically exchanged at intervals of 10 seconds to induce an electric pulse in the culture soil between electrodes.

\subsection{Soil Sampling for Temperature Gradient Gel Electrophoresis (TGGE)}

Soils were collected at five points in the CCS and EPCS on the lab-scale farm field at the initial time, and then at days 21 and 42 during lettuce growth. DNA was extracted from a mixture of soils obtained from the five sampling points using a bead beater (model FastPrep-24, MP Biomedical, Solon, OH, USA) and a DNA extraction kit (Power Soil DNA isolation kit, MoBio Laboratories, Carlsbad, CA, USA).

\subsection{TGGE}

The 16S-rDNA amplified from the DNA extracted from culture soils at the initial time and on days 21 , and 42 of lettuce cultivation or the lettuce root surface at day 42 was employed as a template for the amplification of 16S-rDNA. The 16S-rDNA was amplified with the forward primer (eubacterial V3 region, 341f 5'-CCTACG GGAGGCAGCAG-3') and reverse primer (universal V3 region, 518r 5'-ATTACCGCGGCTGCTGG-3'). A GC clamp (GC-rich DNA oligomer, 5'-CGCCCGCCGCGC GCGGCGGGCGGGGCGGGGGCACGGGGGGCCTA CG-GGAGGCAGCAG-3') was attached to the 5'-end of the GC341f primer [16]. The procedures for PCR and DNA sequencing were identical to the 16S-rDNA amplification conditions except that the annealing temperature was $53^{\circ} \mathrm{C}$. The TGGE system (Dcode, Universal Mutation Detection System, Bio-Rad, Hercules, CA, USA) was operated in accordance with the manufacturer's recommendations. Aliquots $(45 \mathrm{ml})$ of the PCR products were electrophoresed on gels containing $8 \%$ acrylamide, $8 \mathrm{M}$ urea, and $20 \%$ formamide in a $1.5 \times$ TAE buffer system [17] at a constant voltage of $100 \mathrm{~V}$ for $12.5 \mathrm{hr}$ and then at $40 \mathrm{~V}$ for $0.5 \mathrm{hr}$, applying a thermal gradient of $39^{\circ} \mathrm{C}-52^{\circ} \mathrm{C}$. Prior to electrophoresis, the gel was equilibrated to the temperature gradient for $30-45 \mathrm{~min}$.

\subsection{Amplification and Identification of the TGGE Band}

DNA was extracted from the TGGE band and purified

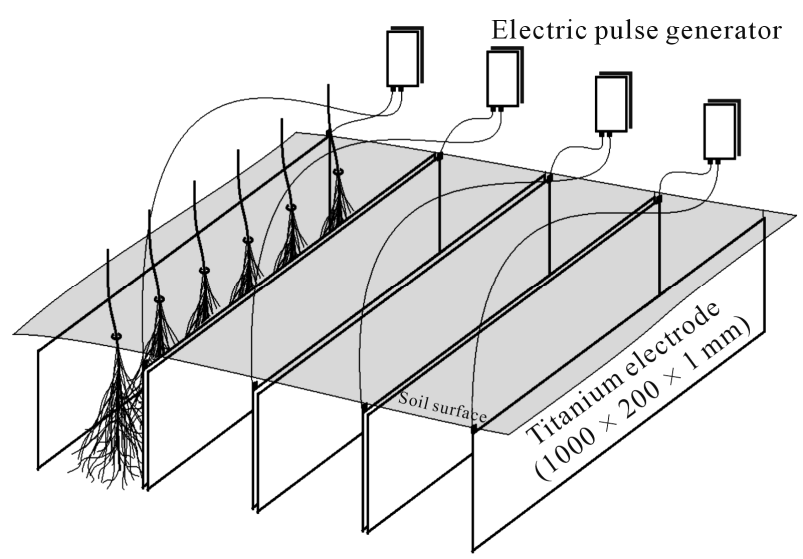

Figure 1. Schematic diagram for electrodes position in culture soil. Electric pole of anode and cathode was periodically exchanged at the intervals of $10 \mathrm{~s}$. 
using a DNA gel purification kit (Accuprep, Bioneer, Daejeon, Korea). The purified DNA was amplified via the same primers and procedures used for TGGE sample preparation, in which the GC clamp was not linked to the forward primer. The species-specific identity of the amplified 16S-rDNA V3 was determined based on the sequence homology in the GenBank database system.

\subsection{Plant Cultivation}

The same number of lettuce or hot pepper plant seeds were sown in culture soil prepared on the lab-scale farm field and germinated and cultivated under conventional conditions or under the $2,4,6,8$, and $10 \mathrm{~V}$ electrically pulsed condition. Two L of water was sprayed on the soil in each compartment at 3 day intervals. Lighting was provided by a plant growth-promoting lamp and adjusted to an illumination intensity of 20,000 lux by measuring at the surface of the compost soil. Air temperature around the lab-scale farm field was maintained at $18^{\circ} \mathrm{C}$ $25^{\circ} \mathrm{C}$.

\subsection{Growth of Lettuce}

The lettuce was harvested and the soil attached on the root surface was removed with water on day 42 of culture in the conventional or electrically pulsed soil. The weight of the lettuce was measured and recorded to compare the effects of electric volt intensity and pulse on lettuce growth.

\subsection{Growth of Hot Pepper Plants}

Because the hot pepper plants were cultivated to obtain hot pepper fruits, the plant was not harvested. Instead, growth duration time and fruiting duration time were observed for 85 days. Hot pepper fruits were harvested and dried whenever they were ripened to red to measure and compare yield according to cultivation conditions.

\subsection{Effect of Electric Pulse on Rooting}

Some branches of young hot pepper plants that were cultivated for 40 days were cut and implanted in CCS or $10 \mathrm{~V}$ of EPCS and cultivated for 14 days. Rooting from the cut branches was observed after soils were removed from the plant body by washing with water.

\section{RESULTS}

\subsection{Variation in the TGGE Patterns}

The TGGE patterns of the 16S-rDNA V3 region obtained from the CCS $(0 \mathrm{~V})$ for lettuce growth were not different from those obtained from the EPCS $(2-10 \mathrm{~V})$; however, the TGGE patterns obtained at the initial time and at days 21 and 42 were changed significantly as cultivation time passed (Figure 2). The difference in cultivation time for plant growth caused a change in the bacterial community but a change in the soil conditions due to an electric pulse charge did not result in a changed soil
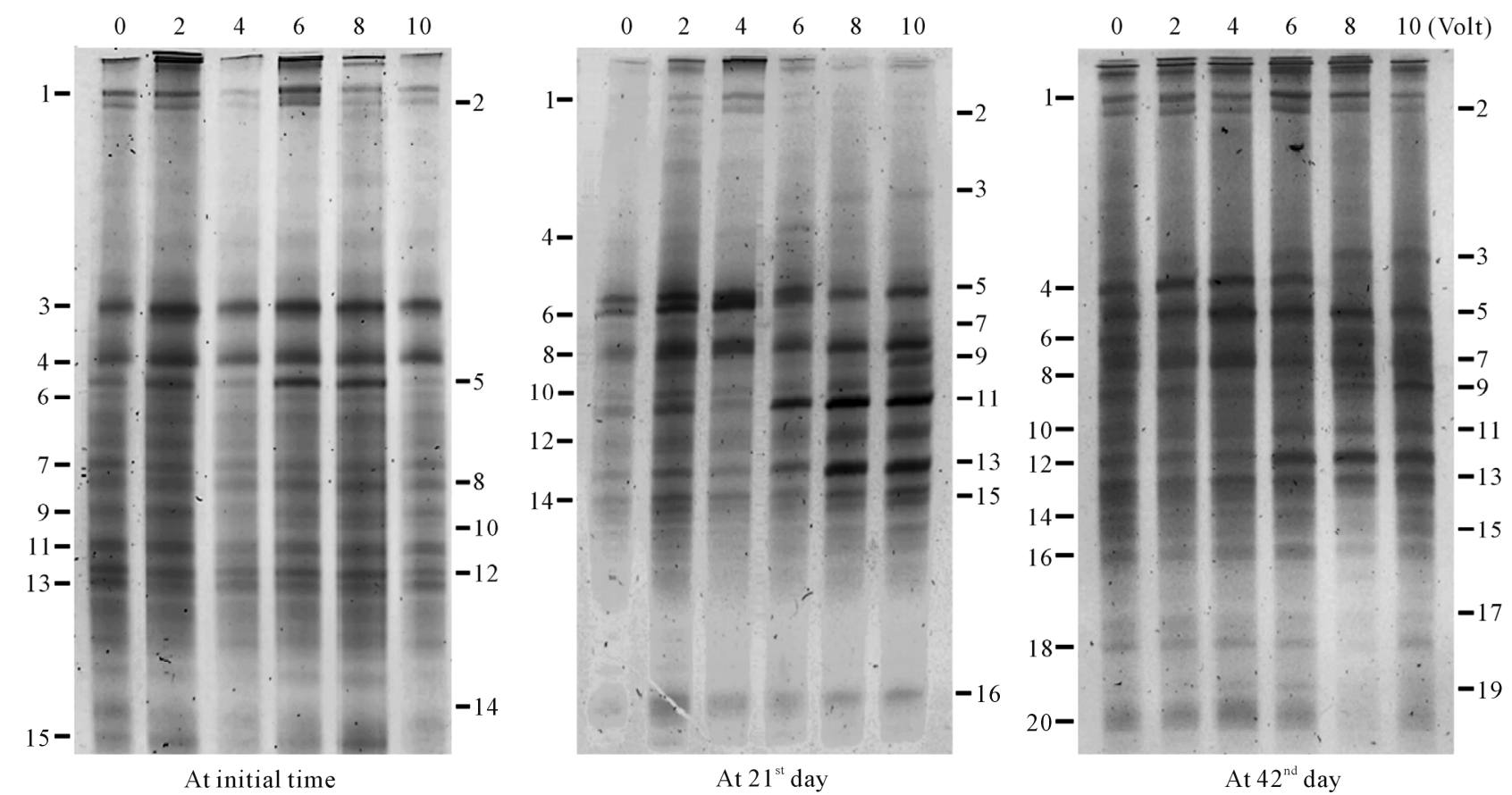

Figure 2. TGGE pattern of 16S-rDNA variable region amplified with genomic DNA extracted from bacterial community inhabiting in conventional culture soil and $2-10 \mathrm{~V}$ of the electrically pulsed culture soil at initial time, $21^{\text {st }}$ day, and $42^{\text {nd }}$ day of cultivation time. 
bacterial community. The TGGE patterns of the 16SrDNA V3 region obtained from the root surface of lettuce grown in CCS $(0 \mathrm{~V})$ were mostly same as those in the $2,4,6,8$, and $10 \mathrm{~V}$ of EPCS but were greatly different from those obtained from the culture soils (Figure 3). These results suggest that the bacterial community was not influenced by the electric pulse but may have changed during lettuce cultivation.

\subsection{Identification of Bacterial Communities}

DNA extracted from the TGGE gel was sequenced and identified based on sequence homology. Most bacteria detected at the initial time belonged to species that inhabit soil or were related to the soil environment; however, some of bacteria detected on days 21 and 42 were species related to plants or the rhizosphere (Table 1). The bacterial community was meaningfully altered during lettuce growth but was not influenced by the electric pulse or intensity. In contrast, the bacterial community separated from the lettuce root surfaces was not altered by the electric pulse and were mostly identified as an uncultured bacterial clone (Table 2). These results

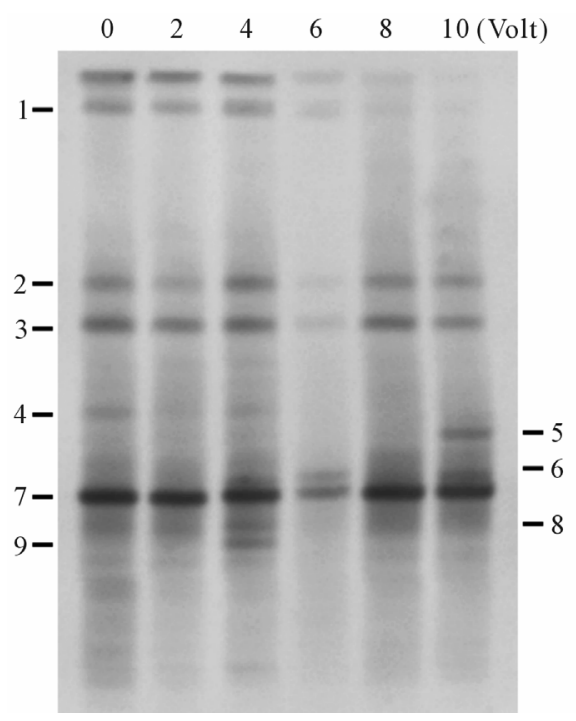

Figure 3. TGGE pattern of 16S-rDNA variable region amplified with genomic DNA extracted from bacterial community inhabited on root surface of lettuces that were cultivated in conventional farm field soil and $2-10 \mathrm{~V}$ of the electrically pulsed soil for 42 days.

Table 1. The homogeneous bacteria with DNAs extracted from the numbered bands in TGGE gel were arranged in the order of the band numbers in Figure 1.

\begin{tabular}{|c|c|c|c|}
\hline DNA band & Soil at initial time & Soil at $21^{\text {st }}$ day & Soil at $42^{\text {nd }}$ day \\
\hline 1 & Uncultured typeII methanotroph & Uncultured Ideonella sp. (Rhizosphere) & Uncultured $\gamma$-proteobacterium \\
\hline 2 & Uncultured $\mathrm{G}(+)$ bacterium & Uncultured soil bacterium & Uncultured bacterium \\
\hline 3 & Uncultured $\delta$-proteobacterium & Mesorhizobium sp. (Rhizosphere) & Rhodanobacter sp. (Rhizosphere) \\
\hline 4 & Uncultured Sphingomonas sp. & Mesorhizoabium sp. (Rhizosphere) & Uncultured cyanobacterium \\
\hline 5 & Uncultured bacterium & Uncultured $\beta$-proteobacterium & Uncultured bacterium \\
\hline 6 & Uncultured bacterium & Blastochloris sulfoviridis (Photosynthesis) & Frateuria sp. (Plant origin) \\
\hline 7 & Staphylococcus sp. & Uncultured bacterium & Uncultured soil bacterium \\
\hline 8 & Uncultured bacterium & Uncultured bacterium & Uncultured bacterium \\
\hline 9 & Beijerinckia sp. & Uncultured soil bacterium & Uncultured bacterium \\
\hline 10 & Agrobacterium sp. & Uncultured soil bacterium & Uncultured bacterium \\
\hline 11 & Methylocella tundra & Uncultured cyanobacterium partial $16 \mathrm{~S}$ rRNA & Uncultured bacterium \\
\hline 12 & Uncultured $\alpha$-proteobacterium & Uncultured $\beta$-proteobacterium & Fulvimonas soil strain \\
\hline 13 & Uncultured bacterium & Uncultured bacterium & $\begin{array}{l}\text { Enriched bacterium clone } \\
\text { AL0_GLFRUDDO3HDS1K }\end{array}$ \\
\hline 14 & Uncultured bacterium & Uncultured soil bacterium & Uncultured bacterium \\
\hline 15 & Uncultured bacterium & Uncultured soil bacterium & Uncultured bacterium \\
\hline 16 & - & Ochrobactrum anthropi & Uncultured $\alpha$-proteobacterium \\
\hline 17 & - & - & Uncultured Bradyrhizobium sp. (Rhizosphere) \\
\hline 18 & - & - & Uncultured bacterium \\
\hline 19 & - & - & Uncultured $\delta$-proteobacterium \\
\hline 20 & - & - & Uncultured bacterium \\
\hline
\end{tabular}


suggest that the bacterial community was influenced by plant growth and cultivation time but not by the electric pulse.

\subsection{Influence of Electric Pulse on Lettuce Growth}

Lettuce growth had to be limited, because about 40 crops of lettuces were densely grown in the limited space of the lab-scale farm field $\left(1200 \mathrm{~cm}^{2}\right)$; however, the growth differences according to culture conditions could be measured (Table 3). Growth of lettuce increased in the $4,6,8$, and $10 \mathrm{~V}$ of EPCS compared to that of the $\mathrm{CCS}$ and $2 \mathrm{~V}$ of EPCS. Thus, the electric pulse may not inhibit lettuce but may help maintain the physiological function of lettuce under dense culture conditions (Figure 4).

\subsection{Influence of the Electric Pulse on Hot Pepper Plants}

Growth of hot pepper plants was not activated by the electric pulse; however, growth duration increased and fruiting duration was proportional to growth duration (Figure 5). Hot pepper fruit yield was also proportional to the growth duration, and weight of the dried fruits increased following the electric pulse treatment (Table 4). This result is novel and shows that an electric pulse may be a useful environmental factor to increase the growth duration of hot pepper plants.

\subsection{Influence of Electric Pulse on Rooted Plant Cuttings}

Rooting from the branch cutting was activated by the electric pulse when fresh branches of hot pepper plants were cut and implanted into the CCS and the $10 \mathrm{~V}$ of EPCS (Figure 6). This result was a physiological example explaining that the growth of lettuce and the growth duration of hot pepper plants were activated or increased by the electric pulse.

\section{DISCUSSION}

Periodic exchange of the anode and cathode may induce an oxidation-reduction reaction on the electrode surface, by which negative and positive electric charge may be alternately generated on both electrodes and diffuse into culture soil [18]. The electric pulse that charges to watered soil may be a kind of energy to induce a change in environmental conditions by migrating electric charges through soil particles [19]. Changes in farm field environments where various soil bacterial communities and rhizobia inhabit may be a cause to induce bacterial community variation [20]. However, the TGGE patterns showed that a $2-10 \mathrm{~V}$ low intensity electric pulse
Table 2. The homogeneous bacteria with DNAs extracted from the numbered bands in TGGE gel were arranged in the order of the band numbers in Figure 2.

\begin{tabular}{cccc}
\hline $\begin{array}{c}\text { DNA } \\
\text { band }\end{array}$ & Root surface at $42^{\text {nd }}$ day & $\begin{array}{c}\text { Accession } \\
\text { No. }\end{array}$ & $\begin{array}{c}\text { Homology } \\
(\%)\end{array}$ \\
\hline 1 & Soil bacterium 12G-05 & EU839183 & 98 \\
2 & Uncultured bacterium clone & HM59573 & 99 \\
3 & Uncultured bacterium clone & JN382481 & 98 \\
4 & Uncultured bacterium isolate & HQ119522 & 99 \\
5 & Uncultured bacterium clone & HM70372 & 96 \\
6 & Uncultured bacterium clone & HQ234669 & 100 \\
7 & Uncultured bacterium clone & GU548734 & 100 \\
8 & Uncultured bacterium clone & JN392917 & 97 \\
9 & Uncultured bacterium clone & JN122937 & 100 \\
\hline
\end{tabular}
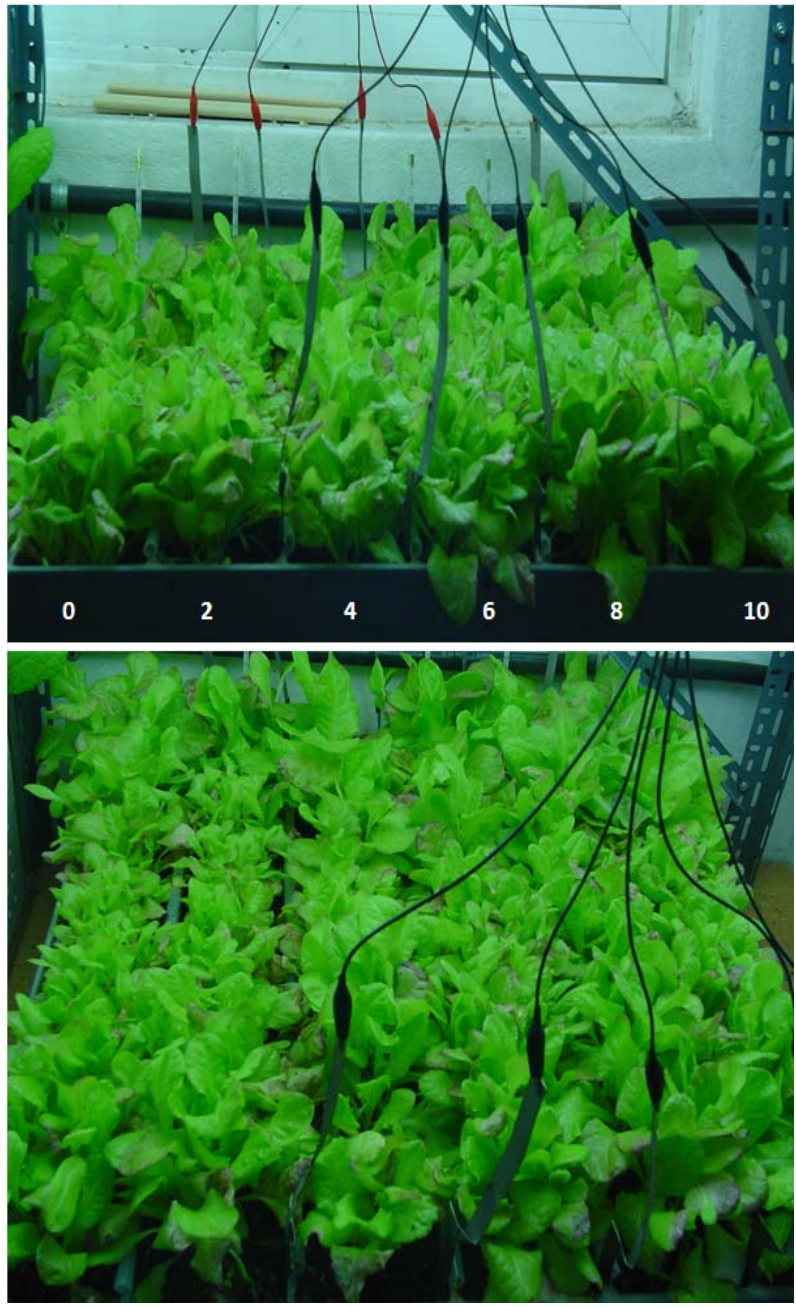

Figure 4. Side view (upper) and wide view (lower) of lettuces cultivated in conventional culture soil $(0 \mathrm{~V})$ and $2-10 \mathrm{~V}$ of the electrically pulsed culture soil for 42 days. 
Table 3. Yield of lettuces cultivated in conventional culture soil (CCS) and $2-10 \mathrm{~V}$ of the electrically pulsed culture soil (EPCS) for 42 days since lettuce seeds were sowed. Fresh lettuces were used to weigh after soils were removed from roots.

\begin{tabular}{ccccccc}
\hline Culture Conditions & CCS & 2 V-EPCC & 4 V-EPCC & 6 V-EPCC & 8 V-EPCC & 10 V-EPCC \\
\hline Number of crop yield & 55 & 51 & 49 & 54 & 53 & 52 \\
Mean weight of crops (g) & $5.43 \pm 0.31$ & $5.86 \pm 0.35$ & $6.57 \pm 0.26$ & $7.38 \pm 0.41$ & $7.26 \pm 0.33$ & $7.34 \pm 0.38$ \\
Total weight (g) & 298.65 & 298.86 & 321.93 & 398.52 & 384.78 & 381.68 \\
\hline
\end{tabular}

Table 4. Yield of hot pepper fruits harvested in conventional culture soil (CCS) and $2-10 \mathrm{~V}$ of the electrically pulsed culture soil (EPCS) during hot peppers were cultivated for 85 days. Hot pepper fruits were harvested and completely dried whenever they were ripened to be red.

\begin{tabular}{ccccccc}
\hline Culture Conditions & CCS & 2 V-EPCC & 4 V-EPCC & 6 V-EPCC & 8 V-EPCC & 10 V-EPCC \\
\hline Number of fruit yield & 36 & 41 & 56 & 54 & 58 & 57 \\
Mean weight of crops $(\mathrm{g})$ & $0.92 \pm 0.14$ & $0.93 \pm 0.14$ & $1.04 \pm 0.09$ & $1.09 \pm 0.17$ & $1.02 \pm 0.14$ & $1.05 \pm 0.15$ \\
Total weight $(\mathrm{g})$ & 33.12 & 38.12 & 58.24 & 58.86 & 59.16 & 59.85 \\
\hline
\end{tabular}
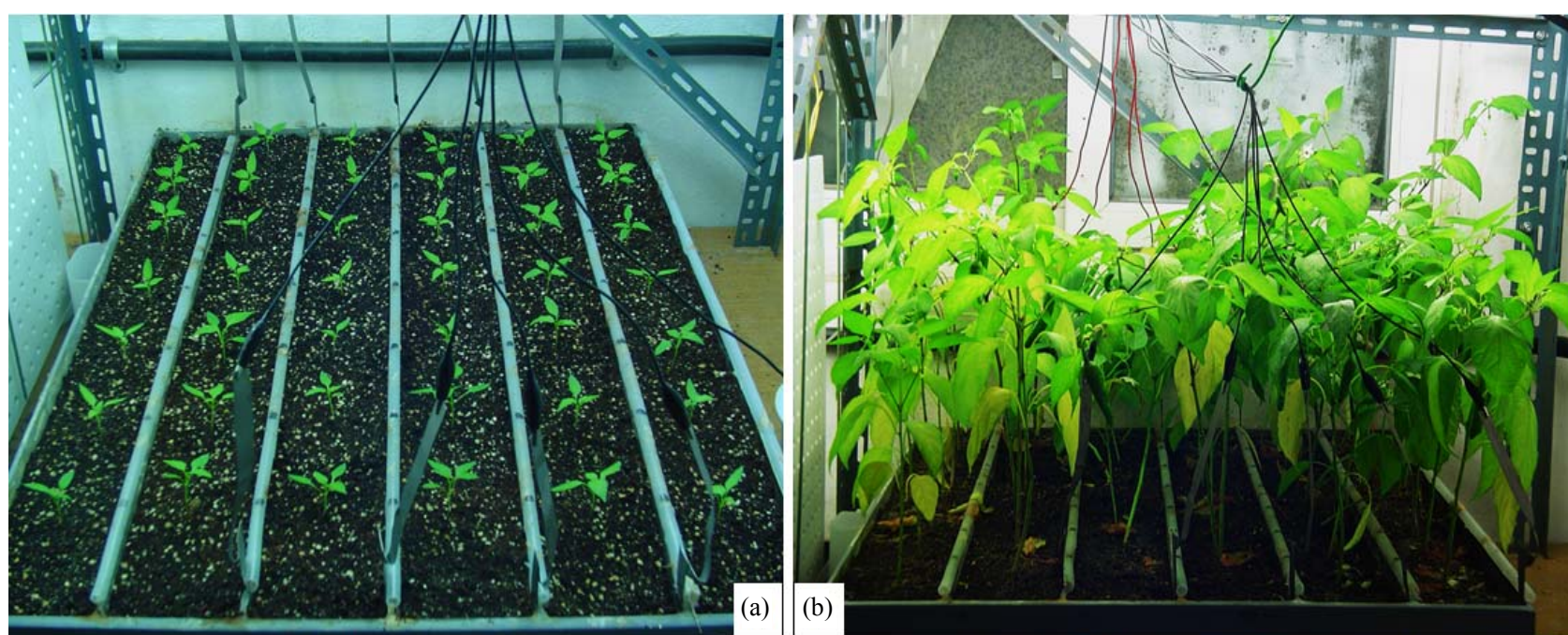

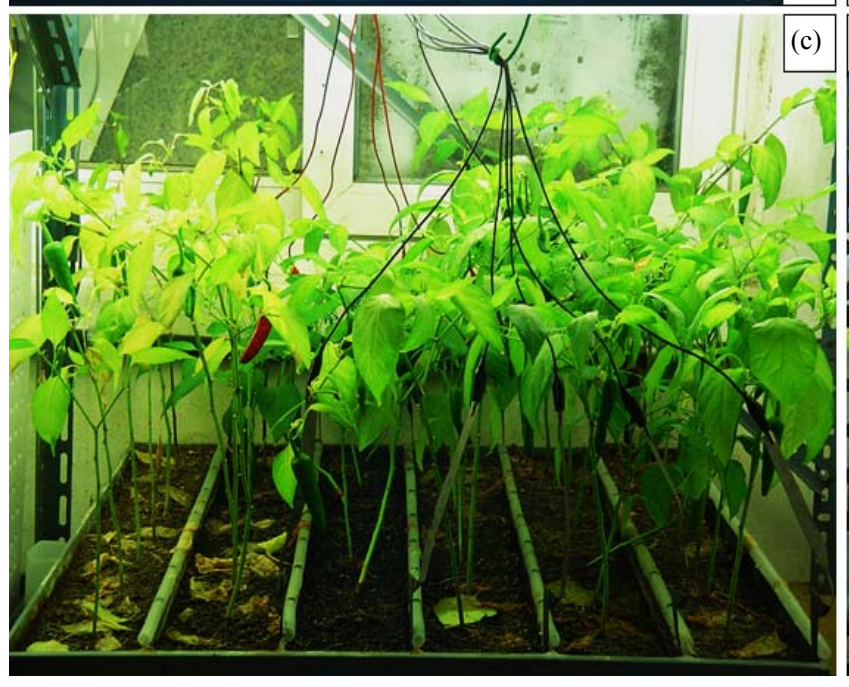

0
2
6

8

$10 \mathrm{~V}$

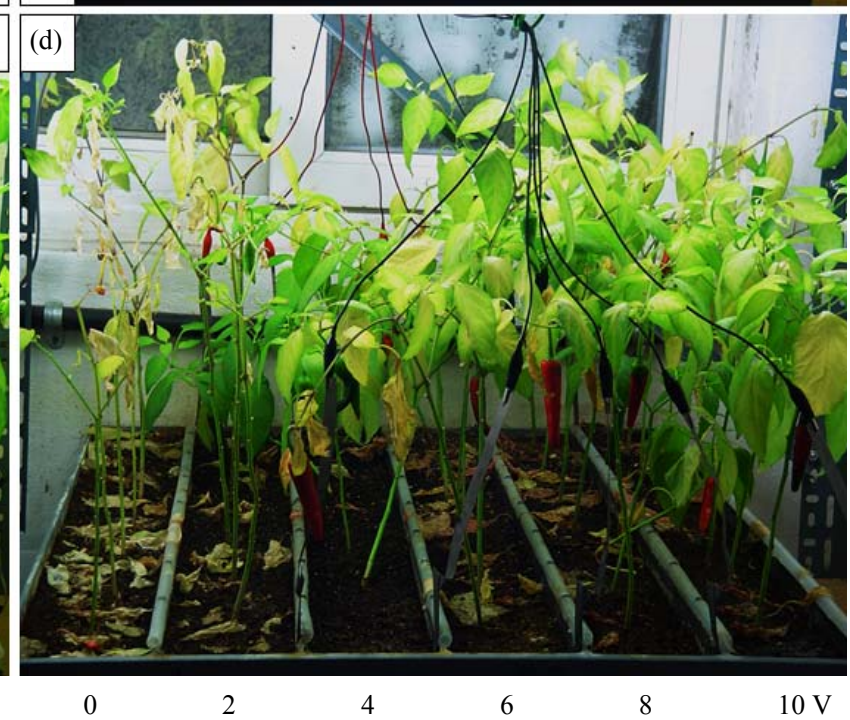

Figure 5. Growth of hot pepper plants cultivated in conventional culture soil $(0 \mathrm{~V})$ and $2-10 \mathrm{~V}$ of the electrically pulsed culture soils. The hot pepper plants were cultivated for 15 days (a), 65 days (b), 75 days (c), and 85 days (d) since their seeds were sowed. 


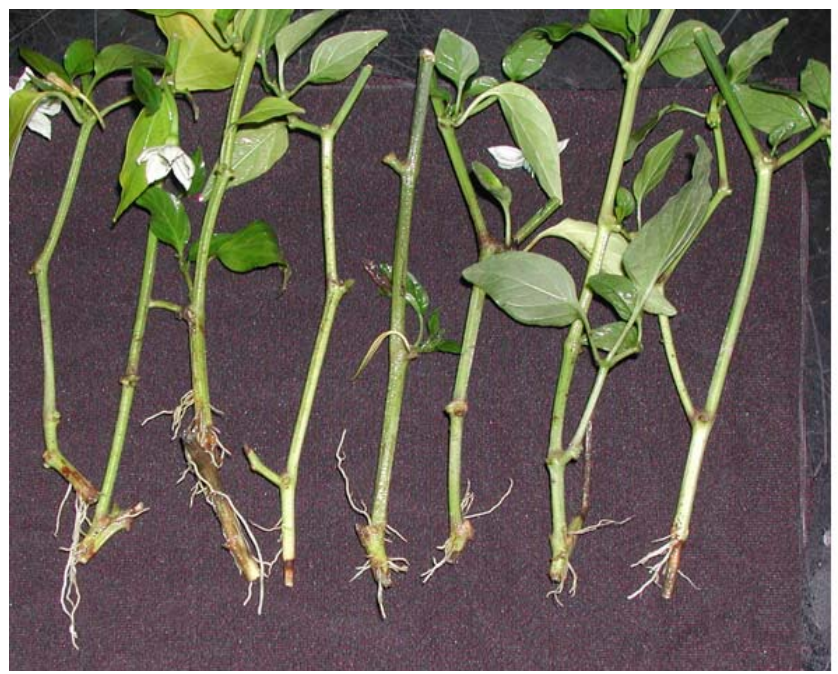

In electrically pulsed culture soil

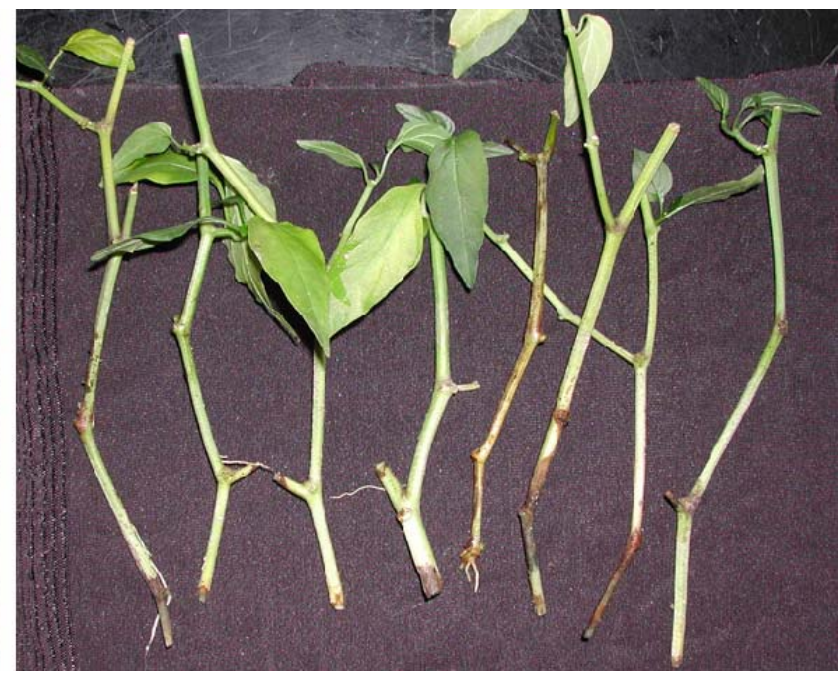

In conventional culture soil

Figure 6. Effect of electric pulse on rooting from branch cutting of hot pepper plant that was cultivated in the electrically pulsed and conventional culture soil.

charged to the culture soil did not change bacterial community structure or diversity. Variations in the soil environment induced by the low intensity electric pulse may be not have been sufficient to impact bacterial growth. The bacterial communities inhabiting the soil very close to an electrode may be relatively strongly influenced by the electric pulse energy, but that is difficult to detect using the TGGE technique. Theoretically, structure and diversity variation in bacterial communities inhabiting soil may be a cause to change soil environments for plant's roots, by which plant growth and physiological function may be activated [21-24]. Bacterial community diversity was not changed by the electric pulse, nevertheless, growth of the lettuce and fruiting (growth) duration of hot pepper plants was activated and increased, respectively, in the $4-10 \mathrm{~V}$ of EPCS. This change in growth caused by the electrical pulses may have been caused by acceleration of the geochemical cycle [25]. Rock phosphate solubilization, which promotes plant growth, is activated by rhizobacteria [26-28]. Phosphate solubilization may also be activated by an electric pulse because the redox reaction and $\mathrm{pH}$ variation are the main processes leading to phosphorus release in peat and calcareous soils [29], which may be an indirect way that soil conditions improved growth of lettuce and growth duration of hot pepper plants. Rooting from plant stem or branch cuttings may be controlled by the physiological functions of the plant under proper temperature, water, light, and oxygen-satisfying conditions but may not be influenced by other environmental factors [30]. The activation of rooting in branch cuttings of hot pepper plants in the EPCS suggests that an electric pulse may be an environmental factor capable of influencing plant physiology but not bacterial community variation.
Conclusively, the low intensity electric pulse charged to the culture soil may not have influenced the bacterial community but improved the environmental conditions for lettuce and hot pepper cultivation. In the future, the impact of an electric pulse on physiological variations in plants using biochemical methods and variations in the mineral content of culture soils using soluble elemental analysis technique will be evaluated.

\section{ACKNOWLEDGEMENTS}

This work was supported by the New \& Renewable Energy of the Korea Institute of Energy Technology Evaluation and Planning (KETEP) grant funded by the Korea governmental Ministry of Knowledge Economy (2010T1001100334).

\section{REFERENCES}

[1] Lee, H.J. and Moon, S.H. (2005) Enhancement of electrodialysis performances using pulsing electric fields during extended period operation. Journal of Colloid and Interface Science, 287, 597-603. doi:10.1016/j.jcis.2005.02.027

[2] Na, B.K., Sang, B.I., Park, D.W. and Park, D.H. (2005) Influence of electric potential on structure and function of biofilm in wastewater treatment reactor: Bacterial oxidation of organic carbons coupled to bacterial denitrification. Journal of Microbiology and Biotechnology, 15, 1221-1228.

[3] Sale, A.J.H. and Hamilton, W.A. (1967) Effect of high electric fields on microorganism. I. Killing of bacteria and yeast. Biochimica et Biophysica Acta, 15, 1031-1037.

[4] Gilliland, S.E. and Spec, M.L. (1967) Inactivation of microorganisms by electric shock. Applied Microbiology, 15, 1031-1037.

[5] Wouters, P.C., Dutreux, N., Smelt, J.P.P.J. and Lelieveld, 
H.L.M. (1999) Effect of pulsed electric field on inactivation kinetics of Listeria innocua. Applied and Environmental Microbiology, 65, 5364-5371.

[6] Somolinos, M., García, D., Condón, S., Maňas, P. and Pagán, R. (2007) Relationship between sublethal injury and inactivation of yeast cells by the combination of sorbic acid and pulsed electric fields. Applied and Environmental Microbiology, 73, 3814-3821. doi:10.1128/AEM.00517-07

[7] Cong, Y., Wu, Z. and Li, Y. (2008) Electrochemical inactivation of coliforms by in-situ generated hydroxyl radicals. Korean Journal of Chemical Engineering, 25, 727731. doi:10.1007/s11814-008-0119-X

[8] Min, H.R., Jeon, B.Y., Seo, H.N., Kim, M.J., Kim, J.C., Kim, J.K. and Park, D.H. (2009) Effect of low intensity pulsed electric field on ethanol fermentation and chemical component variation in a winemaking culture. Food Science and Biotechnology, 17, 2358-1364.

[9] Seo, H.N., Jeon, B.Y., Tran, H.T., Ahn, D.H. and Park, D.H. (2010) Influence of pulsed electric field on growth of soil bacteria and pepper plant. Korean Journal of Chemical Engineering, 27, 560-566. doi:10.1007/s11814-010-0090-1

[10] Volkov, A.G. (2000) Green plants: Electrochemical interfaces. Journal of Electroanalytical Chemistry, 483, 150-156. doi:10.1016/S0022-0728(99)00497-0

[11] Chalmers, J.D.C., Coleman, J.O.D. and Walton, N.J. (1984) Use of an electrochemical technique to study plasmamembrane redox reactions in cultured cells of Daucus carota L. Plant Cell Report, 3, 243-246. doi:10.1007/BF00269303

[12] Pickard, B.G. (1973) Action potentials in higher plants. Botanical Review, 39, 172-201. doi:10.1007/BF02859299

[13] Pickard, W.F. (1969) The correlation between electrical behavior and cytoplasmic streaming in Chara braumii. Canadian Journal of Botany, 47, 1233-1240. doi:10.1139/b69-174

[14] Williams, S.E. and Pickard, B.G. (1972) Receptor potentials and action potentials in Drosera tentacles. Planta, 103, 193-221. doi:10.1007/BF00386844

[15] Racusen, R.H. and Etherton, B. (1975) Role of membrane-bound fixed-charge changes in phytochrome-mediated mung bean root tip adherence phenomenon. Plant Physiology, 55, 491-495. doi:10.1104/pp.55.3.491

[16] Eichner, C.A., Erb, R.W., Timmis, K.H. and WagnerDöbler, I. (1999) Thermal gradient gel electrophoresis analysis of bioprotection from pollutant shocks in the activated sludge microbial community. Applied Environmental Microbiology, 65, 102-109.

[17] Sambrook, J., Fritsch, E.F. and Maniatis, T. (1989) Molecular cloning: A laboratory manual. 2nd Edition, Cold Spring Harbor Laboratory, New York.

[18] Desert, G., Lebender, D. and Schneider, F.W. (1995) Electrical pulses to determine chemical phase response curves. Journal of Physical Chemistry, 99, 11432-11435. doi:10.1021/j100029a021
[19] Nishimura, Y., Ohta, N., Yamamoto, M. and Yamazaki, I. (1998) Electric field effect on the charge migration of methylene-linked carbazole and terephthalic acid metyl ester in PMMA polymer films. Molecular Crystals and Liquid Crystals, 315, 181-186. doi:10.1080/10587259808044329

[20] Doi, T., Morita, S., Abe, J., Zhu, S. and Yamagishi, J. (2009) Analaysis of determining factors on community structure of soil bacteria in volcano ash soil (Kanto Loan) farming field using PCR-DGGE method. International Symposium "Root Reserarch and Applications", Vienna, 2-4 September 2009.

[21] Glick, B.R., Karaturovic, D.M. and Newell, P.C. (1995) A novel procedure for rapid isolation of plant growth promoting Pseudomonads. Canadian Journal of Microbiology, 41, 533-536. doi:10.1139/m95-070

[22] Kennedy, I.R., Perg-Gerk, L.L., Wood, C., Deaker, R., Gilchrist, K. and Katupitiya, S. (1997). Biological nitrogen fixation in non-leguminous field crop: Facilitating the evolution of an effective association between Azospirillum and wheat. Plant Soil, 194, 65-79. doi:10.1023/A:1004260222528

[23] Kleeberger, A., Castroph, H. and Klingmuller, W. (1983) The rhizosphere microflora of wheat and barley with special reference to gram-negative bacteria. Archives of Microbiology, 136, 306-311. doi:10.1007/BF00425222

[24] Sakthivel, N. and Gnanamanikam, S.S. (1987) Evaluation of Pseudomonas fluorescens for suppression of sheath rot disease and for enhances in rice (Oryza sativa L.). Applied and Environmental Microbiology, 53, 2056-2059.

[25] Yamaguchi, K.E. (2001) Evolution of the geochemical cycles of redox-sensitive elements. Frontier Research on Earth Evolution, 1, 249-252.

[26] Freitas, J.R., Banerjee, M.R. and Germida, J.J. (1997) Phosphate-solubilizing rhizobacteria enhance the growth and yield but not phosphorus uptake of canola (Brassica napus L.). Biology and Fertility of Soil, 24, 358-364. doi: $10.1007 / \mathrm{s} 003740050258$

[27] Narsian, V. and Patel, H.H. (2000) Aspertgillus aculeatus as a rock phosphate solubilizer. Soil Biology \& Biochemistry, 32, 559-565. doi:10.1016/S0038-0717(99)00184-4

[28] Hilda, R. and Reynaldo, F. (1999) Phosphate solubilizing bacteria and their role in plant growth promotion. Biotechnology Advances, 17, 319-339. doi:10.1016/S0734-9750(99)00014-2

[29] Shenker, M., Seitelbach, S., Brand, S., Haim, A. and Litaor, M.I. (2005) Redox reactions and phosphorus release in re-flooded soils of an altered wetland. European Journal of Soil Science, 56, 515-525. doi:10.1111/j.1365-2389.2004.00692.x

[30] Mesén, F, Newton, A.C. and Leakey, R.R.B. (1997) The effects of propagation environment and foliar area on the rooting physiology of Cordia alliodora (Ruiz \& Pavon) oken cutting. Trees-Structure and Function, 11, 404-411. 